\title{
Leaf Vein Density of Tree Saplings Composing Lower Canopy in Tropical Forest Reflects Their Ecophysiological Characteristics
}

\author{
Yansen $^{1,2 *}$, Deselina ${ }^{1}$ \\ 1) Department of Forestry, Faculty of Agriculture, University of Bengkulu, Indonesia \\ 2) Ecosystem Management, University of New England, Armidale, Australia
}

Submitted: 26 June 2020; Accepted: 24 August 2020; Published: 15 December 2020

\begin{abstract}
One factor affecting the survival of a species in a tropical ecosystem is its ability to respond to environmental conditions, which depend on their ecophysiological performances. Plants ability to transport water as a major environmental factor would determine their survival. The anatomy of xylem inside leaves and stem as water conductive tissue will dictate the rate of water transport through the plant stem and leaves. Leaf vein, which contains xylem vessels, dictates water transport through leaves and plant's ability to control water loss through stomata. This research found that tree saplings composing a lower canopy of tropical forests have different ecophysiological attributes. Pioneer species, such as Cinnamomum sp., Diospyros macrophylla, Castanopsis costata, Elateriospermum tapos, and Ziziphus sp., have higher leaf vein density than primary species, such as a member of genus Garcinia, Shorea, Dipterocarpus, and Syzigium. It implies that pioneer species might have higher rates of water transport and consequently, higher rates of photosynthesis. If forest vegetation was more opened, then pioneer species may dominate the area as they are more tolerant of light. The Composition of forest vegetation with different ecophysiological characteristics may affect the forest dynamics and hydrological cycle.
\end{abstract}

Keywords: Ecophysiology, leaf vein density, tropical forest ecosystem, water transport

\section{INTRODUCTION}

The efficiency of water to be transported in plants from the soil to the stem and then leaves partly affects plants ability to survive in their environments. This efficiency is driven by several aspects, i.e. the capacity of roots to absorb water from the ground, the rate of water movement in the xylem to the canopy, and the effectiveness of plants to control transpirational water loss from the stomata (Atwell et al., 1999). The structural design of xylem, which is the water conductive tissue, will dictate how water is transported through the stem (Tyree \& Zimmerman, 2002). Therefore it will drive water transport efficiency (Tyree \& Ewers, 1996). The design of xylem includes dimensions of the vessels, hydraulic conductivity, and vulnerability to the formation of embolism. Hydraulic conductivity is

\footnotetext{
*Corresponding author

Tel.: +6281314230426

Email: yansen@unib.ac.id

(C) 2020, J. Tropical Biodiversity Biotechnology (CC BY-SA 4.0)
}

the rate at which water can be transported through xylem at a given pressure (Tyree \& Ewers, 1996). As the structural design of xylem may affect the flow of water from the root to the stem and finally to the leaf, it may consequently dictate stomatal conductance, leaf gas exchange, and water potential.

Variation in hydraulic architecture of plants may partially affect the height that can be attained by the plant and their distributions along environmental gradients and (Tyree \& Ewers, 1996). Plants with different growth forms, such as epiphytes, vines, and trees have different hydraulic architecture characteristics that result in different ecological and physiological adaptations. Hydraulic architecture of woody plants, such as lianas, primary hemiepiphytes, shrubs, and trees have been extensively studied (Drake \& Franks, 2003; Ewers et al., 1991; Patiño et al., 1995; Tng et al., 2018; Tyree \& Ewers, 1996; Tyree \& Zimmerman, 2002). Studies on hydraulic architecture of non-woody plants, 
especially climbing plants, have also been conducted (Ganthaler et al., 2019). These studies include observation of vessel size and density and hydraulic capacity of species of climbing rattans (Fisher et al., 2002; Tomlinson et al., 2001), climbing aroids Monstera acuminata (Lopez-Portillo et al., 2000), and invasive climbing species Merremia peltata (Yansen et al., 2015). Embolism in palm xylem Rhapis excelsa (Sperry, 1986) and the vine Rhipidocladum racemiflorum (Cochard et al., 1994) due to drought condition has also been observed.

However, published researches so far on plant hydraulic architecture were more focused on the individuals and species/group of species levels or growth forms. The contribution of plant hydraulic variations on spatial vegetation dynamics has not been widely discussed. As the hydraulic efficiency could affect plants ability to survive and to regulate water loss from the leaf, information on spatial distribution of hydraulic characteristics of plants composing tropical forests can be used to predict future vegetation dynamics and perhaps its effect on the hydrological cycle.

Leaf vein architecture as part of plant hydraulic has been studied for the last two decades. It has received more attention as it is linked to the physiology, ecology, and evolution of terrestrial plants (Price et al., 2014; Sack \& Holbrook, 2006). Leaf vein architecture, including vein size and density, and hydraulic conductivity, might play as the main constraint in water transport for photosynthesis and transpiration. If this architecture could restrict water transport, then the evolutionary strategy to form more adaptive leaf vein architecture for certain environmental conditions may dictate the fitness of certain species (Boyce et al., 2009; Tabassum et al., 2016). Leaf hydraulic capacity is very much related to the ability of species to utilize water and to exchange carbon in different habitat and vegetational zones (Sack et al., 2005; Bodribb et al., 2007; Pagano \& Storchi, 2015). Therefore, leaf hydraulic architecture is crucial information in observing forest vegetation dynamics, as well as predicting the response of vegetation to environmental changes. This research aimed to observe leaf vein characteristics of tree saplings composing a lower canopy of tropical forests. Those characteristics were then related to their ecophysiological characteristics, such as lightdemanding pioneer species and shade-tolerant primary species (Goodale et al., 2012; Whitmore, 1998).

\section{MATERIALS AND METHODS}

This research was conducted in the protected forest of Boven Lais Kemumu, North Bengkulu, Bengkulu
Province, Indonesia, which is located between $102^{\circ}$ $11^{\prime} 50^{\prime \prime}$ - $102^{\circ} 25^{\prime} 40^{\prime \prime} \mathrm{E}$ (east longitude) and $3^{\circ} 15^{\prime} 24^{\prime \prime}$ $3^{\circ} 33^{\prime} 15^{\prime \prime} \mathrm{S}$ (south latitude). This forest has a high biodiversity of plants with different characteristics. Twenty plots of $10 \mathrm{x} 10 \mathrm{~m}$ were placed systematically from the forest edge into the intact area. These 20 plots were put on four lines; hence one line consisted of five plots with $40 \mathrm{~m}$ distance between plots.

All tree saplings in every plot were recorded and tagged. Tree saplings are categorized as to have $<10 \mathrm{~cm} \mathrm{dbh}$ (diameter of breast height), and $>3 \mathrm{~m}$ tall. Sapling diameter and height were measured. Tree saplings were chosen as the object of this research since it is assumed that saplings are on their optimum growth and they will dominate the ecosystem in the future. Ten fully expanded leaves of each sapling were taken as samples to be analysed their leaf vein characteristics.

Leaf samples were stored in a container containing alcohol. Those leaves were then cleaned with $\mathrm{NaOH}$ and water. Fractions of leaves were placed under a microscope (Olympus) and photos were taken. Leaf vein characteristics were observed using ImageJ software (National Health Institute, USA). Observed leaf vein characteristics include leaf vein level, and leaf vein density per area $\left(\mathrm{mm} / \mathrm{mm}^{2}\right)$. Environmental conditions were also monitored, including humidity, temperature, and light intensity under the canopy.

\section{RESULTS AND DISCUSSION}

The location of the research had relatively dense canopy cover with varied vegetational strata from seedlings to trees. The measurement of environmental conditions shows that observed tree saplings grow under a canopy with high humidity, mild temperature, and low light intensity. No differences in humidity, light intensity, and temperature between forest edge and intact vegetation (Figure 1).

Twenty fives species (13 families) of tree saplings were found on the location (Table 1). Garcinia and Cinnamomum were two commonly genus found on the location. Tree saplings compose the lower stratum of the forest. The range of the diameter of observed saplings was $4 \mathrm{~cm}$ to $9 \mathrm{~cm}$ and the range of height was $4 \mathrm{~m}$ to $8 \mathrm{~m}$.

Tree saplings were distributed from the forest edge into a more intact canopy. Species such as Cinnamomum sp., Garcinia sp., Dipetrocarpus gracilis, and Exoecaria bantamensis were found from forest edge into intact canopy area (Table 2). As explained before, no differences in humidity, light intensity, and temperature between forest edge and intact vegetation (Figure 1). Many factors may affect the 
Table 1. Species and number of saplings per species found at study plots in the protected forest of Boven Lais Kemumu.

\begin{tabular}{cllc}
\hline No & \multicolumn{1}{c}{ Species } & \multicolumn{1}{c}{ Family } & Number of individuals \\
\hline 1 & Artocarpus heterophyllus & Moraceae & 1 \\
2 & Aradirachta sp. & Meliaceae & 6 \\
3 & Castanopsis costata & Fagaceae & 4 \\
4 & Cinnamomum obtusifolium & Lauraceae & 4 \\
5 & Cinnamomum sp. 1 & Lauraceae & 13 \\
6 & Cinnamomum sp. 2 & Lauraceae & 2 \\
7 & Diospyros macrophylla & Ebenaceae & 4 \\
8 & Dipterocarpus gracilis & Dipterocarpaceae & 5 \\
9 & Elateriospermum tapos & Euphorbiaceae & 2 \\
10 & Elmerillia tsiampacca & Magnoliaceae & 2 \\
11 & Excoecaria bantamensis & Euphorbiaceae & 8 \\
12 & Fragraea racemosa & Loganaceae & 3 \\
13 & Garcinia sp. 1 & Clusiaceae & 10 \\
14 & Garcinia sp. 2 & Clusiaceae & 2 \\
15 & Lannea coromandelica & Anarcadiaceae & 1 \\
16 & Litsea sp. & Lauraceae & 2 \\
17 & Macaranga gigantea & Euphorbiaceae & 2 \\
18 & Shorea leprosula & Dipterocarpaceae & 1 \\
19 & Shorea multiflora & Dipterocarpaceae & 1 \\
20 & Shorea siamensis & Dipterocarpaceae & 4 \\
21 & Syzigium oides & Myrtaceae & 3 \\
22 & Syrigium sp. & Myrtaceae & 5 \\
25 & Ziziphus sp. & Rhamnaceae & 1 \\
\hline
\end{tabular}

development of vegetation in a tropical forest, e.g. intra and inter-specific competition, predation, niche differentiation, disturbances, and stochastic recruitment (Brokaw \& Busing, 2000; Goodale et al., 2012; Nathan et al., 2008; Silvestrini \& dos Santos, 2015). With relatively similar environmental conditions in most of the studied forest ecosystem, every species would have similar opportunities to grow both on the edge or more to the middle part of the forest.

The level of leaf vein of observed tree saplings ranges between 3 to 5 levels (Figure 2). Saplings with more leaf vein levels usually have more complex vein arrangement (Figure 3a-c), although they do not necessarily have more dense veins. On the other hand, some other species have a simple leaf vein arrangement (Figure 3d). The range of leaf vein density of observed saplings was 0.02 to $>0.3 \mathrm{~mm} /$ $\mathrm{mm}^{2}$ (Figure 2). Leaf vein density of $0.3 \mathrm{~mm} / \mathrm{mm}^{2}$ means that $30 \%$ of the leaf area consists of veins. In this research, species found to have high leaf vein density include Cinnamomum sp., Diospyros macrophylla, Castanopsis costata, Elateriospermum tapos, and Ziriphus sp. On the other hand, Garcinia, Shorea, Dipterocarpus, and Syzigium tend to have low vein density.

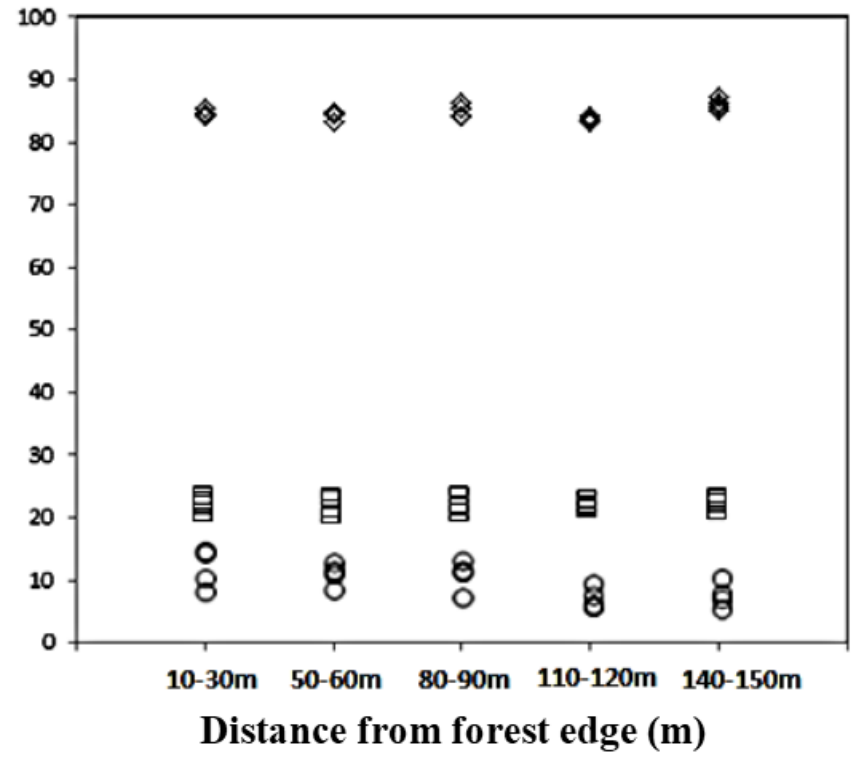

Figure 1. Humidity $(\diamond)(\%)$, temperature $(\square)\left({ }^{\circ} \mathrm{C}\right)$, and light intensity $(0)\left(\mathrm{Watt} / \mathrm{m}^{2}\right)$ of research site with different distances from the forest edge.

Based on their ecophysiological characters, tree sapling species occurring on the studied area can be categorized as pioneer and primary species, following characterization by Whitmore (1998). 
Table 2. The distribution of species based on their distance from the forest edge.

\begin{tabular}{|c|c|c|c|c|}
\hline \multicolumn{5}{|c|}{ Distance from forest edge (m) } \\
\hline $10-30 \mathrm{~m}$ & $50-60 \mathrm{~m}$ & $80-90 \mathrm{~m}$ & $110-120 \mathrm{~m}$ & $140-150 m$ \\
\hline Castanopsis costata & Castanopsis costata & Artocarpus heterophyllus & Azadirachta sp. & Aqadirachta sp. \\
\hline Castanopsis costata & Cinnamomum obtusifolium & Azadirachta sp. & Azadirachta sp. & Azadirachta sp. \\
\hline Castanopsis costata & Cinnamomum obtusifolium & Cinnamomum obtusifolium & Cinnamomum sp. 1 & Azadirachta sp. \\
\hline Cinnamomum sp. 1 & Cinnamomum obtusifolium & Cinnamomum sp. 1 & Cinnamomum sp. 1 & Dipterocarpus gracilis \\
\hline Dipterocarpus gracilis & Cinnamomum sp. 1 & Cinnamomum sp. 1 & Cinnamomum sp. 1 & Dipterocarpus gracilis \\
\hline Dipterocarpus gracilis & Cinnamomum sp. 1 & Cinnamomum sp. 1 & Cinnamomum sp. 1 & Elateriospermum tapos \\
\hline Elateriospermum tapos & Cinnamomum sp. 1 & Cinnamomum sp. 2 & Cinnamomum sp. 2 & Excoecaria bantamensis \\
\hline Elateriospermum tapos & Cinnamomum sp. 1 & Cinnamomum sp. 2 & Cinnamomum sp. 2 & Garcinia sp. 1 \\
\hline Fragraea racemosa & Cinnamomum sp. 1 & Dipterocarpus gracilis & Diospyros macrophylla & Garcinia sp. 1 \\
\hline Litsea sp. & Cinnamomum sp. 1 & Dipterocarpus gracilis & Diospyros macrophylla & Garcinia sp. 1 \\
\hline Macaranga gigantea & Elmerillia tsiampacca & Dipterocarpus gracilis & Diospyros macrophylla & Garcinia sp. 1 \\
\hline Syrigium sp. & Excoecaria bantamensis & Elmerillia tsiampacca & Diospyros macrophylla & Garcinia sp. 1 \\
\hline Syzigium sp. & Excoecaria bantamensis & Excoecaria bantamensis & Garcinia sp. 1 & Shorea leprosula \\
\hline Syrigium sp. & Excoecaria bantamensis & Excoecaria bantamensis & Garcinia sp. 1 & \\
\hline Unknown species 1 & Excoecaria bantamensis & Litsea sp. & Garcinia sp. 1 & \\
\hline Unknown species 2 & Excoecaria bantamensis & Macaranga gigantea & Garcinia sp. 1 & \\
\hline \multirow[t]{8}{*}{ Unknown species 2} & Fragraea racemosa & Shorea multiflora & Garcinia sp. 1 & \\
\hline & Fragraea racemosa & Shorea siamensis & Garcinia sp. 1 & \\
\hline & Shorea siamensis & Shorea siamensis & Garcinia sp. 1 & \\
\hline & Shorea siamensis & Syrigium oides & Garcinia sp. 2 & \\
\hline & Syrigium oides & Syzigium oides & Lannea coromandelica & \\
\hline & Syrigium sp. & Unknown species 2 & Unknown species 1 & \\
\hline & Syzigium sp. & Unknown species 2 & Unknown species 2 & \\
\hline & Unknown species 2 & Ziziphus sp. & & \\
\hline
\end{tabular}

Pioneers are light-demanding and fast-growing species. Their seeds germinate when the environmental conditions favour and the seedlings then quickly grow (Goodale et al., 2012; Silvestrini \& dos Santos, 2015). On the other hand, primary species are shade tolerant (Franklin, 2003). In this research, some species can be categorized as pioneer species, including Cinnamomum sp., Diospyros macrophylla, Castanopsis costata, Elateriospermum tapos, and Ziqiphus sp. Primary species found in the research site include genus Garcinia, Shorea, Dipterocarpus, and Syzigium.

The responses of plants to genotype, age, ontogeny, and environmental heterogeneity result in differences in the ecophysiological performance by the plants (Goodale et al., 2012; Zotz, 2000; Zotz et al., 2001). Light intensity, $\mathrm{CO}_{2}$ uptake, variation in temperature, and humidity, soil fertility and nutrient cycling are prominent environmental entities that affect the dynamics of individuals, as well as the population of plants. The interactions between these environmental factors result in a certain microclimate for the plants to live in. As the environment may vary seasonally and spatially, plants must respond continually and consequently adapt to the change in environmental conditions (Dickison, 2000). Genetic properties and environmental factors will dictate the nature of responses by the plants.

Pioneer species were found to have higher leaf vein density than primary species. High leaf vein density may provide these pioneer species with a higher capacity to transport water (Boyce et al., 2009; Price et al., 2014; Sack et al., 2005; Sack \& Holbrook, 2006). Consequently, pioneer species may have higher rates of photosynthesis and growth. Vegetation is an important part of the hydrological cycle. Forest plants take water up from the ground to the forest canopy. Most of the water then transpires into the air. The amount of water regulated by the vegetation transportation and 


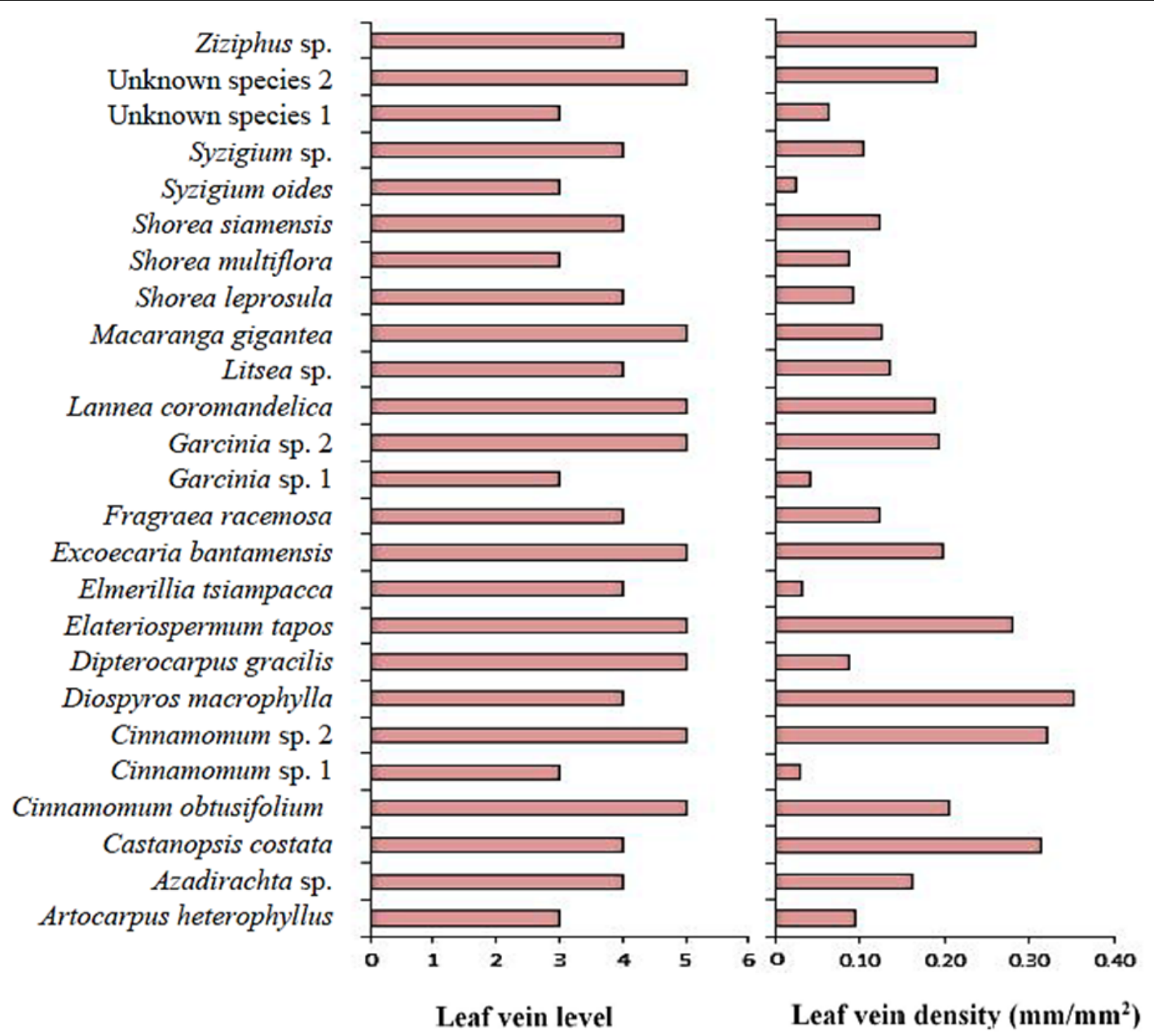

Figure 2. Leaf vein level and density of tree saplings composing lower canopy at the protected forest of Boven Lais Kemumu.
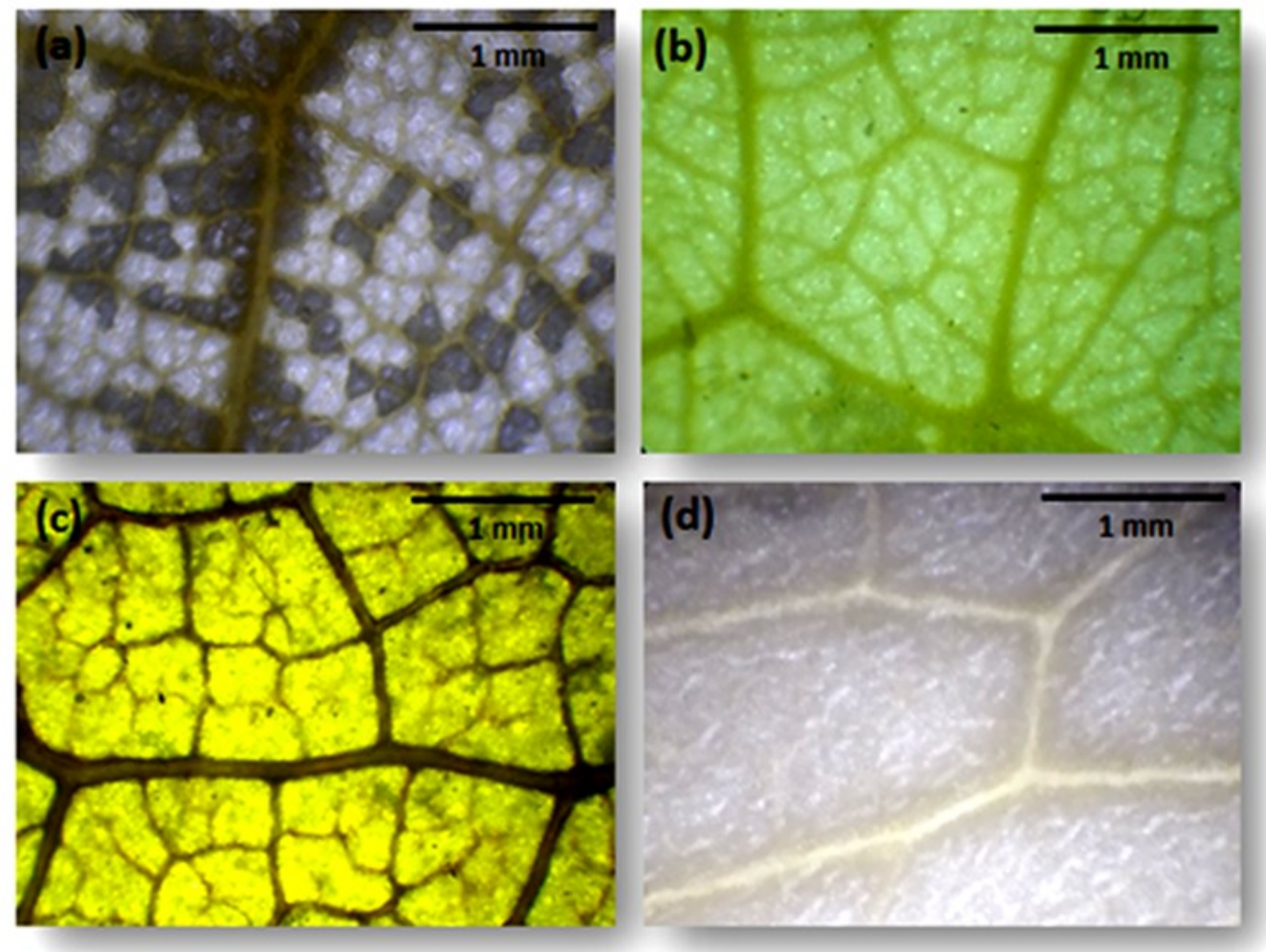

Figure 3. Examples of leaf veins of several tree saplings species found on the protected forest of Boven Lais Kemumu. The species are pioneer species (a) Cinnamomum obtusifolium and (b) Exoecaria bantamensis, and primary species (c) Lannea coromandelica and (d) Shorea multiflora . 
transpiration process in the soil-plant-atmosphere continuum will affect the hydrological cycle in general. Therefore, different compositions of vegetation with different ability to transport water will contribute differently to the hydrological cycle. If the ecosystem becomes more opened, pioneer species may dominate as they are more lightdemanding. As they are physiologically more water demanding to support high rates of photosynthesis, the domination of pioneer species (if happening) will hypothetically affect the hydrological cycle.

\section{CONCLUSION}

Tree saplings composing a lower canopy of tropical forest have different ecophysiological attributes and leaf vein characteristics. Pioneer species, such as Cinnamomum sp., Diospyros macrophylla, Castanopsis costata, Elateriospermum tapos, and Ziriphus sp., have higher leaf vein density than primary species, such as Garcinia, Shorea, Dipterocarpus, and Syzigium. As leaf vein density may affect the capacity of plants to transport water, pioneer species might have higher rates of water transport and higher rates of photosynthesis. Consequently, the composition of forest vegetation with different ecophysiological characteristics will affect the forest dynamics and in the long-term hydrological cycle. Future research is directed to measure water conductivity and transpiration rates. Then, total water transport and transpiration will be spatially analysed and the contribution of the vegetation to the hydrological cycle can be simulated.

\section{ACKNOWLEDGMENTS}

This research was fully funded by the Ministry of Research, Technology, and Higher Education, the Republic of Indonesia, in which the authors thank the institution. Mr. Amdani is thanked for his assistance in the field. This project was conducted in the protected forest of Boven Lais and we thank the Office of Forestry and Plantation, North Bengkulu Regency that has granted a permit to access the forest area.

\section{REFERENCES}

Atwell, B., Kriedemann, P. \&Turnbull, C., 1999, Plants in action, MacMillan Publishers, South Yarra Australia.

Brokaw, N. \& Busing, R.T., 2000, Niche versus chance and tree diversity in forest gaps, Trends in Ecology \& Evolution 15 (5), 183-188.
Boyce, C.K., Brodribb, T.J., Feild, T.S. \& Zwieniecki, M.A., 2009, Angiosperm leaf vein evolution was physiologically and environmentally transformative, Proceedings of the Royal Society B: Biological Sciences 276 (1663), $1771-1776$.

Cochard, H., Ewers, F.W. \& Tyree, M.T., 1994, Water relations of a tropical vine-like bamboo (Rhipidocladum racemiflorum): root pressures, vulnerability to cavitation and seasonal changes in embolism, Journal of Experimental Botany 45 (277), 1085-1089.

Dickison, 2000, Integrative plant anatomy, Hardcourt Academic Press, San Diego.

Drake, P.L. \& Franks, P.J., 2003, Water resource partitioning, stem xylem hydraulic properties and plant water use strategies in a seasonally dry riparian tropical rainforest, Oecologia 137, 321-329.

Ewers, F.W., Fisher, J.B. \& Fichtner, K., 1991, 'Water flux and xylem structure in vines', in N.M. Holbrook \& F.E. Putz (eds), The Biology of Vines, Cambridge University Press, Cambridge.

Fisher, J.B., Tan, H.T.W. \& Toh, L.P.L., 2002, Xylem of Rattans: vessel dimensions in climbing palms, American Journal of Botany 89 (2), 196-202.

Franklin, J., 2003, Regeneration and growth of pioneer and shade-tolerant rain forest trees in Tonga, New Zealand Journal of Botany 41 (4): 669 $-684$.

Ganthaler, A., Marx, K., Beikircher, B. \& Mayr, S., 2019, Are hydraulic patterns of lianas different from trees? New insights from Hedera helix, Journal of Experimental Botany 70 (10), 28112822.

Goodale, U.M., Ashton, M.S., Berlyn, G.P., Gregoire, T.G., Singhakumara, B.M.P. \& Tennakoon, K.U., 2012, Disturbance and tropical pioneer species: Patterns of association across life history stages, Forest Ecology and Management 277, 54-66.

Lopez-Portillo, J., Ewers, F.W., Ageles, G. \& Fisher, J.B., 2000, Hydraulic architecture of Monstera acuminata: evolutionary consequences of the hemiepiphytic growth form, New Phytologist 145, 289-299.

Pagano, M. \& Storchi, P., 2015, Leaf vein density: a possible role as cooling system. Journal of Life Sciences 9, 299-303. 
Patiño, S., Tyree, M.T. \& Herre, E.A., 1995, Comparison of hydraulic architecture of woody plants of differing phylogeny and growth form with special reference to freestanding and hemi-epiphytic Ficus species from Panama, New Pbytologist 129, 125-134.

Price, C.A., Munro, P.R.T. \& Weitz, J.S., 2014, Estimates of leaf vein density are scale dependent, Plant Physiology 164, 173-180.

Sack, L., Tyree, M.T. \& Holbrook, N.M., 2005, Leaf hydraulic architecture correlates with regeneration irradiance in tropical rainforest trees, New Phytologist 167, 403-413

Sack, L. \& Holbrook, N.M., 2006, Leaf hydraulic, Annual Review of Plant Biology 57, 361-81

Silvestrini, M. \& dos Santos, F.A.M, 2015, Variation in the population structure between a natural and a human-modified forest for a pioneer tropical tree species not restricted to large gaps, Ecology and Evolution 5, 2420-2432.

Sperry, J.S., 1986, Relationship of xylem embolism to xylem pressure potential, stomatal closure, and shoot morphology in the palm Rhapis excelsa, Plant Physiology 80, 110-116.

Tabassum, M.A., Zhu, G., Hafeez, A., Wahid, M.A., Shaban, M. \& Li, Y., 2016, Influence of leaf vein density and thickness on hydraulic conductance and photosynthesis in rice (Oryza sativa L.) during water stress, Scientific Reports 6, 36894.

Tng, D.Y.P., Apgaua, D.M.G., Ishida, Y.F., Mencuccini, M., Lloyd, J., Laurance, W.F. \& Laurance, S.G.W., 2018. Rainforest trees respond to drought by modifying their hydraulic architecture, Ecology and Evolution 8, 12479-12491.
Tomlinson, P.B., Fisher, J.B., Spangler, R.E. \& Richer, R.A., 2001, Stem vascular architecture in the Rattan Palm Calamus (ArecaceaeCalamoideae-Calaminae), American Journal of Botanys 88 (5), 797-809.

Tyree, M.T. \& Ewers, F.W., 1996, 'Hydraulic architecture of woody tropical plants', in S. S. Mulkey, R. L. Chazdon, \& A. P. Smith (eds), Tropical forest plant ecophysiology. pp. 217-243, Chapman \& Hall, New York.

Tyree, M.T. \& Zimmerman, M. H., 2002, Xylem structure and the ascent of sap, Springer-Verlag, Berlin.

Whitmore, T.C., 1998, An Introduction to Tropical Rain Forest, Oxford University Press, Oxford.

Yansen, Wiryono, Deselina, Depari, E.K. \& Hidayat, M. F., 2015. The expansion of Merremia peltata (L.) Merrill in fragmented forest of Bukit Barisan Selatan National Park enhanced by its ecophysiological attributes, Biotropia 22, 25-32

Zotz, G., 2000, Size-related intraspecific variability in physiological traits of vascular epiphytes and its importance for plant physiological ecology, Perspectives in Plant Ecology, Evolution and Systematic 3, 19-28.

Zotz, G., Hietz, P. \& Schmidt, G., 2001, Small plants, large plants: the importance of plant size for the physiological ecology of vascular epiphytes, Journal of Experimental Botany 52, 2051-2056. 